\title{
TOPOGRAPHIC MAPPING SUPPORT IN THE SOUTH AFRICAN MILITARY DURING THE $20^{\mathrm{TH}}$ CENTURY
}

\author{
Lt Col André Jacobs and Cdr Hennie Smit ${ }^{\bullet}$ \\ Subject Group Military Geography, \\ Faculty of Military Science, Stellenbosch University
}

\begin{abstract}
Maps provide a base for all intelligence operations and strategic and tactical decisions, supporting the planning and execution of all battlefield functions. The development of military mapping support in South Africa, related closely to the development of aerial photography, may be divided into five, sometimes overlapping, phases. The first of these phases spans the years from 1840 to 1930 and is characterised by the gradual recognition that aerial photographs could be used for mapping. Two major conflicts - the Anglo Boer War and the First World War marked this development. The Second World War is the key event of the second phase (1930-1950), which witnessed a rapid expansion of aerial photo coverage. The third phase (1945-1960) saw the overemphasising of interpretation techniques rather than the analytical use of results, which was rectified during the fourth phase (1955-1962) when the focus shifted to the applied uses of air-photo interpretation. During the third and fourth phases the topographic mapping support ability of the South African military was expanded. The fifth phase (since 1960) commenced with the expansion of data gathering and analysis into portions of the electromagnetic spectrum beyond the small visible sector. During this period the protracted nature of the conflict on the northern border of Namibia (formerly South West Africa) and the war in Angola focused attention on the South African military mapping system. The National Service system allowed for the expansion of mapping units and the thorough mapping of large areas adjoining our borders. Through all five phases, mapping in the South African military has advanced from hand-
\end{abstract}

The authors would like to acknowledge the valuable assistance and insights offered by Lt Col Ian van der Waag of the Faculty of Military Science, Stellenbosch University. 
produced maps to the utilisation of complex equipment that satisfies the sophisticated mapping needs of a modern defence force.

This paper presents a brief history of both mapping support and the mapping units that have served within the South African theatre during the twentieth century. In doing so, the operational importance of topographic maps is also highlighted.

\section{Introduction}

"Those who do not know the conditions of mountains and forests, hazardous defiles, marshes and swamps, cannot conduct the march of an army" Sun Tzu, $400-321$ B.C., The art of War. ${ }^{1}$

"The tremendous volume of maps required by the armies of the world today leaves no doubt about their importance. Global war without reference to maps could not even be imagined, and in individual sectors the high mobility and speed of our new vehicles would be of little value without maps to guide them."

These scholars highlight the vital importance of topographic mapping support to an efficient military practitioner. If these statements were true in $400 \mathrm{BC}$ and in 1944, they are even more so on the modern battlefield. Yet, before outlining the history and development of topographical mapping support in the South African military, it is necessary to describe the process of mapmaking or cartography.

Maps are a means of communication and a way to organise thought. Maps are created to transmit spatial information to its user and the success or failure of a map depends on its power to convey such information. ${ }^{3}$ The process of mapmaking are best described as the stating of a spatial need by a map user (in our case the military practitioner), and the satisfaction of that need by a skilled professional (the military surveyor / cartographer) by depicting the problem area (battlefield) on a map. The completed product may then be used, and in using the map, new needs can be identified and passed to the cartographer. Maps, then, provide a base for all intelligence operations, tactical decisions and tactical operations, and support the planning and execution of most other battlefield functions.

Heinl RD Jr 1966. Dictionary of Military and Naval Quotations. United States Naval Institute. Annapolis, Maryland. p 218.

2 Lobeck AK \& WJ Tellington 1944. Military Maps and Air Photographs: Their Uses and Interpretation. McGraw - Hill Book Company, New York. p 1.

3 Tyner J 1992. Introduction to Thematic Cartography. Prentice Hall, New Jersey. p 7. 


\section{The Anglo Boer War 1899 - 1902}

While some of the earliest British surveys were made in Egypt after the battle of Tel el Kebir (1882), the Anglo-Boer War provided the main impetus for systematic mapping in the British Army. In 1899 the only available maps on the Boer republics were a few sketches of farms. The first Mapping Section, sent out in that year, comprised two officers, four NCOs and a sapper. By the end of the war, there were four Survey Sections and three Mapping Sections in South Africa. During the war Captain Charles Close (later Arden-Close) RE oversaw the first complete map reproduction in the field - the surveying, drawing and printing of the maps - by the British Army. ${ }^{4}$

Several sources comment on the unavailability of accurate maps for the British during the War. Sir Richard Temple noted that

"as to maps, there is the strangest misconception on the subject among many English people at home. Because maps exist in Europe it seems to be supposed that such things exist everywhere, or that if they do not exist the English Government can and ought to make them. Well, the English have managed to make maps of every coast, or almost every coast in the world; but when you come to make maps inland, that depends on whether the country is enemies' country or not. If, of course, the enemy has made maps for himself and published them, we can get hold of them; but if he has not, then he will not let us make them, and we must do without them when we come to fight."

He concluded that Paul Kruger and M.T. Steyn had not allow mapping of their territories by the British prior to the war and that this accounted for the poor maps available to the soldiers during the early phases of the war. ${ }^{5}$ Temple of course did not mention that the British had done very little when the Boer republics were under British control.

Many references are also made to the inadequacy of the existing maps. At the Tugela, Sir Redvers Buller had to rely on a survey done by the Field Intelligence Department and on a micro-filmed map sent by carrier pigeon from Ladysmith. The blueprint bore the bold legend that "vacant spaces indicate that data is wanting rather

Hodson Y \& A Gordon 1997. An Illustrated History of 250 years of Military Survey. Military Survey Defence Agency, s.l. p 14.

5 Briggs L 1901. The Staff work of the Anglo - Boer War, 1899-1902: Embodying Some of the War Letters Sent to the "Morning Post" from South Africa. Grant Richards, London. pp 174-175. 
than that the ground is flat!". ${ }^{6}$ The inaccuracy of these maps contributed to the debacle at Colenso, for example when Major-General Sir FitzRoy Hart led his men into a loop of the Tugela and on to a wrong drift with the resultant loss of many lives. $^{7}$ Due to this lack of good maps, sketches of the country were made and the ranges to important points measured with the artillery range-finder. Copies of these sketches were printed and issued to officers. ${ }^{8}$ According to Maurice the cost of compiling maps of the Transvaal and Free State on a scale of four miles to the inch, would have taken five years to complete, and at a cost of $£ 150,000$. The state of tension between the Transvaal Republic and Britain made such an undertaking impractical if not impossible.

At the outbreak of the Anglo Boer War the British possessed maps on a scale of twelve and a half miles to the inch for the Cape Colony, the Orange Free State and a part of Natal. These maps were issued to their army in South Africa. For the Northern part of Natal two military maps were available. These, however, were known to be inaccurate and hopelessly out of date. In January 1900 a thousand copies of a survey of Transvaal farms were seized at Cape Town, and maps were compiled from them by the Field Intelligence Department and sent to the front. ${ }^{10}$

On the Boer side, accounts regarding the availability and uses of maps differ from those of the British. According to many sources, the Boers used a system - in the first stages of the war, at least - of assigning Boer soldiers as close as possible to their home districts, so ensuring good local knowledge even in the absence of maps. Boer leaders, including such legends as C.R. de Wet, consulted with these soldiers, who briefed Boer commanders before battle. ${ }^{11}$ Officers were instructed to improve their knowledge of the "quick drawing of sketch maps of the terrain". Although official sources do not indicate whether maps were used to plan battles and troop movements, the Boer republics were able to produce maps for this purpose: both

Pakenham T 1995. The Boer War. Abacus, London. p 208.

Breytenbach JH 1971. Die geskiedenis van die Tweede Vryheidsoorlog in Suid-Afrika, 1899-1902. Deel 2: Die eerste Britse-offensief, November-Desember 1899. Die Staatsdrukker, Pretoria. p 267; Pakenham T 1995. The Boer War. p 227.

Waters WHH 1904. The War in South Africa. John Murray, London. p 49.

Maurice F 1906. History of the War in South Africa, 1899 - 1902. Volume 1. Hurst and Blackett Limited, London. p 14.

Maurice F 1906. History of the War in South Africa, 1899 - 1902. p 15.

Pretorius F 1999. Life on Commando during the Anglo-Boer War 1899-1902. Human \& Rousseau, Cape Town. p 211; Rabie JE 1980. Generaal C.R. De Wet se krygsleiding by Sannaspos en Groenkop. SAW Dokumentasiediens, Pretoria. p 6; Breytenbach JH 1969. Die geskiedenis van die Tweede Vryheidsoorlog in Suid-Afrika, 1899-1902. Deel I: Die Boere-offensief, Oktober-November 1899. Die Staatsdrukker, Pretoria. p 133. 
republics had a Department of the Surveyor General, which made accurate maps of every farm in the two republics. ${ }^{12}$

The Boer forces had the following maps at their disposal: a map by F. and C. Jeppe of the South African Republic on a scale of 1 inch to 8 miles, published in $1899^{13}$; a map of the Orange Free State produced by J.J. Herfst in 1891, and also a map of the first two rows of farms on the Free State side of the border with the Cape Colony and Natal. The last map was produced at the insistence of President Steyn of the Free State at a conference in November 1898 and was specifically intended for military purposes. As far as the British Colonies were concerned, the Republics also had two military maps of Northern Natal. These were "produced during the previous wars on a scale of four miles and one mile to an inch", as well as a map of the Cape Colony on a scale of 1 inch to $12^{1 / 2}$ miles, produced in $1895 .{ }^{14}$

Yet, despite this, the Boers apparently preferred to operate without maps. Breytenbach gives one possible explanation for this. ${ }^{15} \mathrm{He}$ concluded that most of the Burghers, and even their officers, had a poor understanding of geography and the reading of maps and rather used their phenomenal knowledge of the veldt in the planning and execution of battles. Most Boer soldiers had a good knowledge of vast areas of the Transvaal, Orange Free State and even parts of Natal and the Cape Colony from their campaign experience of 15 or more wars fought in the forty years preceding the Anglo Boer War. ${ }^{16}$ The very nature of the commando system meant that large numbers of Boers fought in some (even most) of these wars and as a result knew the military potential of areas far away from their homes without having to refer to maps.

At the start of the Anglo Boer War both the British and the Boer forces had to rely on inaccurate, outdated maps produced on scales that made even the more accurate maps practically worthless for tactical purposes. The British responded to this by sending surveying and mapping units to the front and by updating existing maps, as opposed to the Boer generals who relied upon local knowledge. During the latter stages of the war the British had better maps at their disposal and could also

12 Breytenbach JH 1969. Die geskiedenis van die Tweede Vryheidsoorlog. pp 61,134135.

13 This map, depicting relief features and drainage patterns as well as farm boundaries and names, was of high value for military purposes during the Anglo Boer War (Liebenberg E 2003. From Barrow to Jeppe - The development of $19^{\text {th }}$ Century cartography in South Africa. Proceedings of the Simposium on The History of Cartography of Africa, Cape Town, South Africa, 4-5 August 2003, p 118).

14 Breytenbach JH 1969. Die geskiedenis van die Tweede Vryheidsoorlog. pp 134-135. Breytenbach JH 1969. Die geskiedenis van die Tweede Vryheidsoorlog. p 134.

Anon 1986. A Short Chronicle of Warfare in South Africa. Militaria 16(3) pp 40-47. 
enlist the service of joiners who were as familiar with the terrain as the opposing Boer forces in the field.

\section{The First World War $1914-1918$}

Although the necessity of a national mapping programme was discussed in 1904, this never materialised due to a lack of funding. The British War Office mapped the Orange River Colony at a scale of 1:125 000 and the north-west Cape at 1: 250 000, but not much mapping was done after that. ${ }^{17}$ The Union Defence Force (UDF) was established in July 1912 and two years later the UDF was subjected to its first campaign, the distant conflict in Europe bringing the invasion of German South West Africa. ${ }^{18}$ Although sources regarding this and the subsequent campaigns of the First World War are vague on the mapping support available to the South African forces, a few points may be deduced.

Firstly, for the German South West Africa campaign, General Louis Botha utilised existing lines of communication for the launch of attacks. This campaign was largely conducted according to the old Boer doctrine, with scouts undertaking the reconnaissance and then presenting briefs to their commanders. The use of maps was probably limited and the British War Office produced those in use. ${ }^{19}$

Secondly, as Van der Waag has shown, until December 1917, the Union Defence Force was entirely dependent upon British sources for their intelligence. ${ }^{20}$ During the campaigns in East Africa, Europe and Egypt, the South Africans relied on British logistical support, and what was true for the British forces, probably applied to the South Africans as well. The First World War was the first war in which troops were provided in advance with adequate small-scale maps. As soon as the trench warfare started, larger scale maps were produced from 1:80 000 sheets, but were later compiled from aerial photographs and original surveys. These maps

17

Chief Directorate Surveys and Mapping 2003. History of National Mapping in South Africa. [Online] Available: http://w3sli.wcape.gov.za/surveys/Mapping/maphist.htm [06.05.2003]. 18 Dorning WA 1987. A Concise History of the South African Defence Force, 1912 -
1987. Militaria 17(2)pp 3-4; Nötling CJ 1994. Suid-Afrika in die Eerste Wêreldoorlog, 1914 - 1918. Suid-Afrikaanse Militêr-Historiese Konsultante, Silverton. p 23; Bouch RJ (ed) 1977. Infantry in South Africa: 1652-1976. Documentation Service SADF, Pretoria. p 53.

19 Bouch RJ (ed) 1977. Infantry in South Africa. p 53; Dorning WA 1987. A Concise History of the South African Defence Force. p 4; L'ange G 1991. Urgent Imperial Service: South African Forces in German South West Africa, 1914 - 1915. Ashanti Publishing, Rivonia. pp 141-142, 204.

20 Van der Waag IJ 1995. Major J.G.W. Leipoldt, D.S.O.: A portrait of a South African Surveyor and Intelligence Officer, 1912-1923. Militaria 25(1) p 22. 
were on a scale of 1:20 000. Aerial photography therefore opened a new chapter in the history of surveying and mapping and was used extensively during this phase. ${ }^{21}$

In his article on Major J.G.W. Leipoldt, Van der Waag has also shed some light on surveying work done during and immediately after the First World War. During 1917 Major Leipoldt was called back from recuperative leave to survey and produce a topographical map of Saldanha Bay that had to be sufficiently precise to "allow the design of coast defences should they ever be required here" After completing this task he was transferred to Defence Headquarters as a first step in the creation of a small Intelligence Sub-Branch: the 'I' staff comprised Leipoldt and one non-commissioned officer. Their primary function was to gather intelligence inside the borders of the Union. Yet, despite the state of war, the Intelligence Sub-Branch spent an average of only $£ 60.7 .2$ per month as at that stage the Union still received most, if not all, of her Intelligence from the British War Office. ${ }^{22}$

\section{Between two World Wars 1919 - 1938}

After the war Leipoldt's small section was disbanded and no organised Intelligence existed in South Africa. In a 1920 report Leipoldt pointed out that the Union had no contemporary maps, road reports or reconnaissance surveys on the areas adjoining the border with Mozambique, and none whatsoever of the Portuguese territory itself. The report provided the impetus for the establishment of an Intelligence Section at Defence Headquarters in 1921 and of a national Intelligence Section in the office of the Chief of the General Staff on the $1^{\text {st }}$ of September 1923. In terms of the Manual of Military Intelligence (1921), the War Office expected the Dominions to conduct do their own surveying and mapping and to present copies of these products to the War Office. The position of the Union Defence Force regarding maps was unenviable. It lacked maps for more than half of the surface of South Africa itself. Practically the whole coast was not suitably mapped to allow for military operations. ${ }^{23}$ In view hereof, Leipoldt appealed for the formation of a Survey Corps and when this did not materialise he resigned in April 1923. The survey function was allocated to the South African Engineer Corps, which was established as part of the reconstituted Permanent Force on 1 February

$21 \quad$ Hodson Y \& A Gordon 1997. An illustrated history of 250 years of Military Survey. p 16.

22 Van der Waag IJ 1995. Major J.G.W. Leipoldt, D.S.O. pp 21-23.

23 Van der Waag IJ 2000. The Union Defence Force Between the two World Wars, 19191940. Scientia Militaria 30(2) p 197. 
1923. ${ }^{24}$ During 1936 a landmark decision was made to map the country at 1:50 000 and that aerial photography be used for this purpose. ${ }^{25}$

Leipoldt's dream of a Survey Corps was partly realised on 1 April 1938 when the First Field Survey Company was established as an Active Citizen Force unit of the South African Engineer Corps. The foundations for future mapping and surveying in the South African military were thus laid.

\section{The Second World War 1939 - 1945}

Great Britain declared war on Germany in 3 September 1939 and a South African declaration followed three days later. South Africa's wartime frontier was in Kenya, guarding against a possible invasion of British East Africa from neighbouring Italian colonies and on 20 December 1939 the British Government suggested move of South African forces to Kenya. Italy entered the war on 11 June 1940 and the UDF troops moved north to East Africa. ${ }^{26}$ True to the peacetime practise of using civilians where possible, the UDF had appointed Mr William Whittingdale, Director of Trigonometrical Survey, as the military Director of Survey, with the rank of lieutenant colonel, as early as 7 January 1936. And, under the guidance of Major N.G. Huntley, then Assistant Director of Survey, the $1^{\text {st }}$ Field Survey Company had been formed. In May 1940 this unit was mobilised and on 3 June the men were concentrated at Premier Mine for training before leaving for Nairobi. ${ }^{27}$

\subsection{The East African Campaign, June 1940 - November 1941}

The $1^{\text {st }}$ SA Division was accordingly dispatched to East Africa to assist the hard-pressed British forces, who were endeavouring to hold an 800 mile front against Italian forces that had overrun British Somaliland and advanced southward into Kenya from their base in Abyssinia. ${ }^{28}$ As Orpen and Martin point out, in an undeveloped country like Kenya increasing road construction would be necessary to ensure mobility for the South Africans, who were building up the first fully motorised army ever seen in Africa. ${ }^{29}$ Almost the whole area across the frontier was

\footnotetext{
$24 \quad$ Van der Waag IJ 1995. Major J.G.W. Leipoldt, D.S.O. pp 27, 31-34.

25 Chief Directorate Surveys and Mapping 2003. History of National Mapping in South Africa. [Online] Available: http://w3sli.wcape.gov.za/surveys/Mapping/maphist.htm [06.05.2003].

26 Bouch RJ (ed) 1977. Infantry in South Africa. pp 139-140.

27 Orpen N \& HJ Martin 1981. Salute the Sappers. Part 1: The Formation of the South African Engineer Corps and its Operations in East Africa and the Middle East to the Battle of Alamein. Sappers Association, Johannesburg. p 21.

28 Dorning WA 1987. A Concise History of the South African Defence Force. pp 4-5.

29 Orpen N \& HJ Martin 1981. Salute the Sappers. Part 1. p 22.
} 
so densely wooded that vehicles could seldom move off existing tracks. Crosscountry movement by motor transport was extremely difficult and the inaccuracy of existing maps, which even ignored mountain ranges and depicted non-existent roads made planning more hazardous. ${ }^{30}$ Air reconnaissance helped little, as pilots found it almost impossible to judge the suitability of ground for cross-country motoring. Existing maps, suitable for strategic purposes, were tactically of little or no value, and planning of operations was therefor a gamble. ${ }^{31}$

East Africa was largely uncharted and may have remained so, had it not been for South Africa: her Government Survey Department despatched a survey company to Kenya for that purpose. The $1^{\text {st }}$ Field Survey Company, under Majors Walter F. Short and N.G. Huntley, comprised a Trigonometric Group of five sections: a Geodetic Section and an Instrument Repair Section as well as a Map Production Section and a Mapping (Photo-Topo) Group of two sections. The two sections of the Photo-Topo Group, whose personnel were trained and equipped to produce maps from either air photos or by ground methods, joined the Company in December, while the Lithographic Section of the Mobile Map Printing and Printing Company was attached to the Survey Company at about the same time. ${ }^{32}$ The $1^{\text {st }}$ Field Survey Company with its Headquarters, complete with the necessary trained geodetic officers, computers, map production staff, draughtsmen, instrument repairers and other technicians were deployed in Kenya over the period July and December 1940.

However vital transport was to success, roads and maps were of equal priority. With the accent on mobility, the vital importance of road and railway construction was obvious and called for survey support other than topographical mapping. When war began the only available maps were those made for district officers or by the Italians. All were grossly inaccurate, misplacing some geographic phenomena and even ignoring others. ${ }^{33}$ These poor maps and a lack of reliable information on cross-country routes and water supplies handicapped operations. According to Orpen the captured Italian maps which were drawn from aerial photographs were also inaccurate and therefore of little use. ${ }^{34}$

\footnotetext{
30 Orpen N 1968. East African and Abyssinian Campaigns. Purnell, Cape Town. pp 2728.

31 Anderson K 1964. Nine Flames. Purnell, Cape Town. p 43; Orpen N 1968. East African and Abyssinian Campaigns. $\mathrm{p} 95$.

32 Anderson K 1964. Nine Flames. p 45.

33 Brown JA 1990. The War of a Hundred Days: Springboks in Somalia and Abyssinia, 1940-41. Ashanti, Johannesburg. p 69.

34 Orpen N 1968. East African and Abyssinian Campaigns. pp 136; 204.
} 
The only map available for operations was an out-of date 1:1000 000 series that was quite inadequate for military purposes. The official mapping of the area was therefore started on a 1: 500000 scale using mainly data from Italian maps in addition to other sources. The $1^{\text {st }}$ Field Survey Company had trained geodetic and map production staff, enlisted from the goldmines of the Witwatersrand, as well as draughtsmen and instrument repairers who could take a reconnaissance plane's photographs and produce accurate maps without delay. ${ }^{35}$ Army printers made speedy on-the-spot reproductions in their mobile print shops so that when the men at the front went into action they were supplied continuously with maps that were sufficiently detailed for operational purposes. The $1^{\text {st }}$ Field Survey Company delivered the first Kenyan maps by road on 26 December, only 11 days after the arrival of the two mapping sections from South Africa. The surveyors covered 240 $\mathrm{km}$ in 12 days on foot under appalling conditions to make the necessary observations. $^{36}$ Strip maps of important roads were compiled from aerial photographs supplied by the South African Air Force's No 60 (Survey/Photographic) Squadron. Maps were constantly revised, as new data became available from the detail gathered from these strip maps. Artillery maps on a 1: 25000 scale as well as large scale regional maps were also prepared from aerial photographs. $^{37}$

Their success in East Africa and experience gained there was of inestimable value to the SAEC. ${ }^{38}$ According to Wessels this campaign was an Engineers' war, faced as they were with the enormous number of roads, bridges, airstrips and other construction work that had to be build, all an impossible task without prior surveying. ${ }^{39}$ The $1^{\text {st }}$ Field Survey Company was redesignated the South African Survey Company and after completing the final, enormous task of compiling a gazetteer of more than 22000 place names covering 54 maps for the East African Survey Group was transferred to Egypt through the Eritrean port of Massawa.

\footnotetext{
Brown JA 1990. The War of a Hundred Days. p 70.

Orpen N 1968. East African and Abyssinian Campaigns. 65.

Anderson K 1964. Nine Flames. p 44; Orpen N 1968. East African and Abyssinian Campaigns. pp 34-35; Orpen N \& HJ Martin 1981. Salute the Sappers. Part 1. pp 6970,78 .

38 Liebenberg EC 1973. Die topografiese kartering van Suid-Afrika, 1879-1972: 'n Histories-geografiese ontleding. MA thesis, University of South Africa, Pretoria. p 346.

39 Wessels A 1995. Die aanwending van die Unie-Verdedigingsmagte in die tydperk September 1939 tot September 1941. Journal for Contemporary History 20(1) p 16.
} 


\subsection{The North African Campaign, June 1941 - November 1942}

After arriving at Maadi, south of Cairo, the SA Survey Company commenced map production with Royal Engineer assistance and were assigned responsibilities all over the Middle East and North Africa, on a survey connection of Palestine, Egypt and Transjordan major triangulations. ${ }^{40}$

Moving in a poorly mapped country, such as the Western Desert, where landmarks were rare, most units had great difficulty keeping track of their own locations at any given moment. At the end of each day the South African Engineer Corps' surveyors were probably the only men with a column who could accurately fix its position by means of an astrofix to within less than a kilometre in about an hour. With more time available, providing dust, clouds or rain did not limit visibility, this might be done more accurately. ${ }^{41}$

Though units in the forward areas may hardly have been aware of it, since their maps arrived as usual, back at Maadi on 2 April 1942 the SA Survey Company was changed to a Type B Survey Company (non operational). The commanding officer, Lt Col W.F. Short, 13 officers and 103 other ranks were struck off strength and posted to 45 Survey Company. Returned to South Africa, they conducted a crash survey of a strip, about $150 \mathrm{~km}$ wide, around the entire Southern African coast from Mozambique to Angola, in view of the Japanese threat. They also trained troops, awaiting posting to North Africa, in survey work. From among the lines of 45 Survey Company at the Ladysmith military base, 49 Survey Company was formed, only to join the North African and Italian campaigns at a later stage. A newlyestablished Type A Survey Company (operational), redesignated 46 Survey Company, under command of Major N.T. Pascaul remained in North Africa with the field groups carrying on in the desert as before. On 9 July 1942, the Survey Company was placed on a completely mobile basis, so ushering in a new phase. The company was now capable of operating under field conditions more effectively than those envisaged for a British corps field survey company, though it was not immediately possible to move the whole unit into the field. ${ }^{42}$

On 27 July 1942 the entire unit came under the operational command of the $8^{\text {th }}$ Army, and by 9 August the mobile detachment was on its way up to the Western Desert. Almost immediately the detachment began reprinting existing sheets as the

Orpen N \& HJ Martin 1981. Salute the Sappers. Part 1. p 208.

Orpen N \& HJ Martin 1981. Salute the Sappers. Part 1. pp 237, 240.

Smith JR 1995. Capt RS Webb ,RFA(1892-1976). From Shropshire to Paarl via Geodesy and Lesotho. South African Council for Professional and Technical Surveyors, Johannesburg. p 39; Anderson K 1964. Nine Flames. p 20; Orpen N \& HJ Martin 1981. Salute the Sappers. Part 1. pp 322-323, 406-407. 
field group surveyed them. As air cover extended, overprints depicting information about the enemy were made and the provision of adequate maps for future use by the $8^{\text {th }}$ Army daily approached completion. The Mobile Detachment produced block plots of the enemy defence line from air photos and some of the existing sheets produced by the original SA Survey Company the previous year, which proved to be highly accurate as the $8^{\text {th }}$ Army's counter-battery fire was particularly successful. A captured German document dated 18 September 1942, confirmed the enemy's high regard for their accuracy. All work other than that for the $8^{\text {th }}$ Army was handed over to the Director of Survey, Middle East. Navigation parties were provided for the advance and 46 Survey Company took its place permanently among Army Troops, with whom it was to continue serving with outstanding success. ${ }^{43}$

Maintaining the closest contact with 285 Wing, Royal Air Force, the company covered $1120 \mathrm{~km}$ during November, producing 70 maps representing 133 000 impressions for $8^{\text {th }}$ Army. The 46 Survey Company shouldered sole responsibility for the production of battle maps for $8^{\text {th }}$ Army, providing the divisions with field sections for navigation and artillery survey, and obtained ground control for mapping enemy lines from aerial photographs. Having turned out a 1:200 000 six-colour map in exceptionally good time, and printing 9000 copies in 16 hours, 46 Survey Company was released from $8^{\text {th }}$ Army. It returned to Cairo to reorganise and refit before leaving for service in Europe. ${ }^{44}$

\subsection{The Italian Campaign, July 1943 - May 1945}

The last major theatre of operations in which South Africans participated during the Second World War was the Allied campaign in Italy, where conditions were very different to those of the North African theatre. Troops had to operate in mountainous country ideally suited to defensive warfare. In summer, rain and mud, in winter, snow and intense cold, impeded mobility and presented little scope for turning movements. This type of war made heavy demands on all arms, but particularly the Engineers. ${ }^{45}$

The first SAEC unit to set foot on the European continent in World War II was Major G.E. Marriott's 46 Survey Company. Now under command of the $5^{\text {th }}$

$43 \quad$ Anderson K 1964. Nine Flames. p 190; Orpen N \& HJ Martin 1981. Salute the Sappers. Part 1. pp 407, 228-229.

$44 \quad$ Orpen N \& HJ Martin 1982. Salute the Sappers. Part 2: The Operations of the South African Engineer Corps in the North African and Italian Theatres of War from the Battle of El Alamein to the End of World War II, with a Brief Description of Subsequent Developments. Sappers Association, Johannesburg. pp 54, 63; Anderson K 1964. Nine Flames. pp 187-193.

45 Dorning WA 1987. A Concise History of the South African Defence Force. p 12. 
Army, the surveyors immediately began work on a considerable programme of map revision. Trigonometric control for the artillery on the whole Army front was in a bad state and affected the accuracy of the guns. Provision and maintaining of triangulation was carried out at such speed and precision that the accuracy of fire greatly improved. This was the beginning of a long period of most distinguished service rendered the Allied cause in Italy by South African surveyors and soon the highest authorities realised that no one but a highly qualified surveyor stood much chance of getting a commission in a South African survey unit. The standard of the ranks was also well above what was thought acceptable in British and American survey companies. The South Africans were primarily professional surveyors and not professional soldiers with some knowledge of survey and were far better qualified for intricate and accurate triangulation than their British or American counterparts, however good the latter might be at military map reading. The South African surveyors could cover the whole front more effectively than anyone else, identifying old or selecting new unmistakable reference points, and calculating their co-ordinates by survey for distribution to artillery and other units. They also prepared accurate maps from aerial photographs, updated existing Italian and other maps, and produced especially gridded aerial photographs for the Americans. The work of 46 Survey Company earned special appreciation, being amongst the first four recipients of the $5^{\text {th }}$ US Army service plaque and clasp "for excellence in discipline, performance and merit" in making surveys along the entire army front and absorbing the normal function of an American topographic battalion. ${ }^{46}$

The 49 Survey Company of Major J.H. Scott left Ladysmith in South Africa and, arriving in the Middle East on 18 December 1943, was placed under the $5^{\text {th }}$ US Army in January 1944. Here they took over part of the map revision programme from 46 Survey Company and received a steady stream of orders for maps and enlargements. With the 49 Survey Company transferred to $8^{\text {th }}$ Army, South African surveyors became responsible for surveying on both American $5^{\text {th }}$ Army and the British $8^{\text {th }}$ Army fronts. In addition, as a particular service to the air forces, 49 Survey Company found the exact co-ordinates of selected distant targets in complicated conversions of the Yugoslav, Austrian and other grids to the Italian grid. This made computation of both flight time and exact course to a target from any airfield in Italy possible. With the complete Italian trigonometric data captured 49 Survey Company checked and identified trigonometric stations for the $8^{\text {th }}$ Army in addition to now routine map revision and map printing. Neither the American nor the British artillery units could have done without the accurate trigonometric survey details provided by the two South African units and to the very end of the Italian

46

Orpen N \& HJ Martin 1982. Salute the Sappers. Part 2. pp 64-66, 84; Anderson K 1964. Nine Flames. p 199. 
campaign remained dependant on the 46 and 49 Survey Companies for their primary survey information. The two lithographic sections attached to the survey companies, which had printed no fewer than 7512000 maps during their tour of duty, became non-operational during June 1945 and by the end of September were disbanded and all printing activities ceased. The 49 Survey Company was dissolved on 23 October $1945 .^{47}$

\section{The period $1946-1973$}

All three survey units served with distinction throughout the war, after which 45 and 49 Survey Companies were disbanded and only 46 Survey Company, SAEC (ACF), established on 1 August 1946, continued as an active unit in the South African Army. During the post-war period (1946-1961) the Survey Company was split up on a regional basis with headquarters in Johannesburg and sections in Cape Town, Durban, Johannesburg and Stellenbosch. On 1 January 1954 the unit was renamed 46 Survey Squadron, SAEC and again on 31 January 1959 when it became 46 Survey Squadron. From 1963 to 1968 the Squadron carried out extensive mapping tasks for both military and civilian purposes in the Transvaal and Namibia (formerly South West Africa). The 46 Survey Squadron has, since 1963, had very close links with the Survey and Mapping Chief Directorate, formerly Trigonometrical Survey, and much of its work has been of great value to both military and civilian surveyors. ${ }^{48}$

After numerous establishments and disbandments of printing and survey elements in the SAEC, 4 Survey and Printing Regiment was formed on 1 January 1967, as a unit for both the Permanent Force and Citizen Force. ${ }^{49}$ On 1 July 1969, 45 Survey Squadron SAEC (CF) was re-established as a unit of the SA Army, with its headquarters in Pietermaritzburg. A small number of officers and men was detached and transferred from 46 Survey Squadron to form the nucleus of the new unit. The Squadron updated, from a military point of view, the 1:50 000 topographical maps of South Africa and Namibia, and the 1:10 000 orthophoto series in KwaZulu Natal. $^{50}$

$47 \quad$ Anderson K 1964. Nine Flames. pp 199-200; Orpen N \& HJ Martin 1982. Salute the Sappers. Part 2. pp 89, 134, 143, 352-353, 363.

48 SA Sapper 1993. The $50^{\text {th }}$ Anniversary of 45 and 46 Survey Squadrons. SA Sapper 45(1) pp 2-3.

$49 \quad$ Anon 1990. Parade Programme. South African National Defence Force Archives. Unit History File: 4 Survey and Mapping Regiment (SAEC), v 2.

50 SA Sapper 1993. The $50^{\text {th }}$ Anniversary of 45 and 46 Survey Squadrons. $p 2$. 


\section{The war in Angola}

In August 1965 the first group of South West African People's Organisation (SWAPO) insurgents entered Ovambo via Angola from Zambia. The South African Police and later the South African Defence Force tried to stem this growing tide and with the permission of the Portuguese government conducted cross border raids against SWAPO bases. In April 1974 the Portuguese government was ousted in a coup d'etat and a civil war broke out between the three Angolan freedom movements, União Nacional para Indepêndencia Total de Angola (UNITA), the Movimento Popular de Libertação de Angola (MPLA) and Frente Nacional de Libertação de Angola (FNLA). With Russia backing the MPLA, and the USA supplying the FNLA and UNITA with weapons, South Africa became involved in the civil war on the side of UNITA and the FNLA. ${ }^{51}$

During the initial stages of the South African involvement, the South Africans had no accurate maps and had to rely on xeroxed copies of popular road maps. The reason for this sorry state of affairs was that the Portuguese were for many years friends of the Republic of South Africa and there seemed no reason to obtain maps of areas under their government. Low clouds, thick fog and generally overcast skies made the use of aerial photography for map compilation extremely difficult. $^{52}$

After a decision to separate the SAEC's surveys and mapping responsibilities from the Quartermaster General's printing function, 47 Survey Squadron under Major F.H. du Preez, was formed on 1 April 1975. The need for military survey and mapping of the SA Army at that time was to be satisfied by this Squadron. According to Orpen \& Martin a Permanent Force nucleus was thus provided for a vital Sapper task which could become even more essential if the continuing "low intensity" conflict along the border should ever worsen. ${ }^{53}$

These three survey squadrons executed all future survey and mapping needs of the South African Defence Force. From 1975 the survey squadrons then became actively involved with survey and mapping tasks in Namibia and Angola. The lack of maps was overcome when usable maps of parts of the front used by the enemy fell into South African hands and were used by 47 Survey Squadron to produce, within 14 days, working 24 hours a day, a large number of maps of Southern Angola. Ironically, some of these maps never reached the front and were found in unmarked boxes at Grootfontein after they vanished during transport to the

\footnotetext{
51 Spies FJ 1989. Operasie Savannha: Angola 1975-1976. Staatsdrukker, Pretoria. pp 20, 29,72.

$52 \quad$ Spies FJ 1989. Operasie Savannha. pp 78, 103, 124, 158.

53 Orpen N \& HJ Martin 1982. Salute the Sappers. Part 2. p 372.
} 
operational area. When the South African invasion force of Operation Savannha withdrew from Angola in 1976, a total of 752 million rand was spent on the production and distribution of maps. ${ }^{54}$

During 1980 members of 47 Survey Squadron were deployed in Sectors 10, 20 and 70 at Oshakati, Rundu and Mpacha respectively. These field-mapping offices had the responsibility to annotate, update, reproduce and supply maps as needed by the territorial forces. The surveyors or cartographic draughtsmen were also responsible for the preparation of target sketches and target enlargements for use during the planning of operations. In April 1979, 47 Survey Squadron received its first annual intake of national service women, and though trained internally as cartographic draughtsmen, they were never deployed in the Namibian operational area. As from 1981 surveyors surveyed terrain for the building and upgrading of military bases at Okanguati, Omauni, Ondangwa Air Base, 203 Battalion and elsewhere. In 1984 satellite surveying equipment was used for the first time to determine the correct co-ordinates of all airstrips in Sector 10. The following year beacons were surveyed and built at all military bases for air photo control and navigation. These beacons were used to calibrate all mobile navigation equipment used by the South African forces for accurate navigation during operations. This navigation network was later extended to Sector 20 as well as southeastern Angola. ${ }^{55}$

During January and February 1976 as part of a feasibility study, the first terrain evaluation under military operational conditions in south-western Angola was carried out by two civilian scientists, Professor H.J. von M. Harmse of the Potchefstroom University for CHE (now Northwest University) and Dr D. Edwards of the National Botanical Institute of South Africa. This study confirmed the practicality of the system under operational conditions and also fulfilled the need for a rapid overall terrain analysis of the region. The culmination of this study eventually resulted in the formal establishment of a terrain trafficability troop under 47 Survey Squadron, but stationed at Potchefstroom, where graduate national servicemen were trained at Potchefstroom University as terrain evaluators and advisers. After the first national service terrain evaluation officers completed their formal basic and specialist training in December 1983 they were placed in the Citizen Force. Both officers and supporting troops served in the SWA operational area at the various field-mapping offices until the end of the war. In the absence of formal terrain intelligence maps for countries outside the RSA, and to assist terrain evaluators and the military, work also started at the troop in Potchefstroom on the

Spies FJ 1989. Operasie Savannha. pp 161, 312.

Prins AP 1992. Kartering (Unpublished manuscript on the history of the South African Engineer Corps). Directorate Documentation Centre, Pretoria. pp 2-3. 
preparation of a series of reconnaissance scale terrain maps, based on satellite imagery of which the total area covered eventually culminated to some two million square kilometres. ${ }^{56}$

\section{After the 'Bush War',57}

During 1989, with the former South West Africa on its way to independence as Namibia, 47 Survey Squadron deployed for the first time a Mobile Terrain Intelligence Troop (MOBTIT), fitted in Samil 20 trucks, with the ground forces at Army Battle School. The MOBTIT was again deployed at Messina and De Brug during 1991 and thereafter annually to assist in the exercises at Army Battle School.

In 1990 Project Atlanta became a reality for 47 Survey Squadron with the acquisition of a nine million rand computer assisted mapping system. This, the first of its type in the country, placed military mapping right in front with its civilian counterparts in an era of digital mapping techniques, integrated with computerised surveying, as opposed to the conventional hand-drawn methods in use since the start of the century. In 1992 the South African Defence Force commenced restructuring and the two citizen force squadrons, 45 and 46 Survey Squadrons, now commemorating their $50^{\text {th }}$ anniversaries, were brought under command of 47 Survey Squadron, only to be amalgamated on 2 June 1992 into 4 Survey and Mapping Regiment as it is known today.

Two major changes took place in 1994. Firstly, all the outlying squadrons, namely 45 and 46 Survey Squadrons, and the Terrain Trafficability Squadron were closed down and moved back to the Regiment HQ and secondly, the regiment moved to new premises at the SA Army Engineer Formation, where it resides today. In 1995 the MOBTIT was expanded with the addition of a Mobile Printing Section, now refitted into six-metre Cargo containers mounted on Samil 100 trucks to bring 4 Survey and Mapping Regiment into play regarding the concept of mobile warfare. During March 1995 women members joined an all Engineer Corps field exercise 'Super Sapper' at Bethlehem as staff of the MOBTIT for the first time, before partaking in a field exercise at Army Battle School later that same year. ${ }^{58}$ The MOBTIT has since been renamed the Tactical Terrain Intelligence Troop

\footnotetext{
56 Edwards D 1992. Terreinbegaanbaarheidskartering (Unpublished manuscript on the history of the South African Engineer Corps). Directorate Documentation Centre, Pretoria. pp 1-2.

57 This section is largely based on the personal experience of Lt Col J.A. Jacobs, one of the authors of this article, who served with 47 Survey Squadron and 4 Survey and Mapping Regiment from 1977 to 1995 and as Commanding Officer from 1994 to 1995.

58 SA Sapper 1994. Super Woman, Super Sapper. SA Sapper 46(4) p 23.
} 
(TACTIT), which was deployed operationally for the first time as part of the newly established South African National Defence Force's stabilisation force in Lesotho during May-November 1998, where it took full responsibility for all tactical mapping and printing requirements.

Technologically 4 Survey and Mapping Regiment has advanced from an organisation that produced maps by hand to a unit that renders mapping by means of highly modernised equipment. Some of the latest additions to the unit are the Global Positioning Systems and the Geographical Information Systems.

\section{Conclusion: into the next millennium?}

The historical development of military topographic mapping in South Africa coincided with world-wide developments. The technological advances during each of the wars that saw South Africa participation can be clearly recognised. The South African military mapping support systems have come a long way since the inadequate maps of the Anglo Boer War. Today the South African National Defence Force have the ability to utilise the most advanced technology to provide military practitioners with the best decision-making tools available. The military can be rightly proud of the past achievements of its mapping units. The decorations these units received, the dedication with which they executed their tasks and the quality of products they delivered has done them proud. Without the mapping units the South African war operations would simply not have been as successful.

It is also imperative to learn from past mistakes. It is not known where technological advances will lead to in the new millennium. In less than ten years hardcopy maps, as it is known today, may be replaced by small, handheld, palmsized super computers with the ability to communicate with satellites, bringing the most recent terrain data to the soldier on the battlefield within milliseconds. Whatever the case, never again can the South African National Defence Force afford to downscale its surveying and mapping abilities during peacetime. It is therefore of the utmost importance that the military utilises much of its peacetime effort in the preparation of maps and the building of a topographic database of its areas of interest. The wars of the future will be fought from electronic maps that will be the visualisation of the digital battlefields. The present crisis in Northern and Central Africa and South Africa's involvement in peacekeeping operations there, are vivid reminders that the ability to supply soldiers with the best and most reliable maps possible, must be maintained.

It is only fitting to conclude with a quotation by Frederick the Great on the importance of good terrain information and reconnaissance. In his Instructions to his Generals (1747) he stated that 
"when it is desired to apply oneself to this essential part of war, the most detailed and exact maps of the country that can be found are taken and examined and re-examined frequently. If it is not in time of war, the places are visited, camps are chosen, roads are examined, the mayors of the villages, the butchers, and farmers are talked to. One becomes familiar with the footpaths, the depth of the rivers, the marshes that can be crossed and those which cannot... The road is chosen for such and such a march, the number of columns in which the march can be made estimated and all strong camping places on the route are examined". 59

$59 \quad$ Heinl RD Jr 1966. Dictionary of Military and Naval Quotations. United States Naval Institute. Annapolis, Maryland. p 266.

Scientia Militaria, South African Journal of Military Studies, Vol 32, $\mathrm{Nr} 1$, 2004. http://scientiamilitaria.journals.ac.za 